\title{
Nutritional characterization of Cicer arietinum L. cultivars with respect to morphological and agronomic parameters
}

\author{
Enrica De Falco ${ }^{1}$, Rossella Imperato ${ }^{1}$, Giuseppe Landi ${ }^{2}$, Valeria Nicolais ${ }^{1}$, \\ Anna Lisa Piccinelli ${ }^{1}$ and Luca Rastrelli ${ }^{1 *}$
}

${ }^{1}$ Department of Pharmaceutical Science. University of Salerno, Via Ponte Don Melillo, 84084 Fisciano (SA) - Italy; ${ }^{2}$ Department of Crop System Forestry and Environmental Science, University of Basilicata, Macchia Romana, 85100 Potenza - Italy

\begin{abstract}
Chickpea (Cicer arietinum L.) is one of the grain legumes more interesting for its nutritional value and genetic improvement in order to resistance to Aschochyta rabiei, seeds weight and adaptation to mechanical harvesting. The aim of this research was the agronomic and qualitative characterization of 15 cultivars of chickpea. During the cultural cycle resistance and sensitiveness to Aschochyta rabiei were analyzed. At harvesting, grain yield and yields components were registered. Moreover, proximate composition, fatty acids content and saturated/unsaturated ratio of grain samples were determined. Cultivars with high 1000 seeds weight showed a more favourable oleic acid content and unsaturated/saturated ratio but those with smooth seeds had a higher content in linolenic acid. All cultivars showed high values of polyunsaturated fatty acids (42.9-56.2\%), inferior of monounsaturated (29.5-36.1\%) and low of saturated (10.0-22.9\%). Black chickpea (2.9) had the lowest unsaturated/saturated ratio, while the highest was noticed for cv. Visir (7.46). Cultivars with small and smooth seeds showed a better proteins content. These results showed availability of seeds with favourable characteristics useful for different utilization. In particular, the cultivars with small and smooth seeds, usually not preferred by consumers, seem to be interesting for processing in nutritional foods and dietetics.
\end{abstract}

Keywords: Cicer arietinum, dietetics, fatty acids, grain yield, nutritional value, proximate composition, GC/MS.

$$
\begin{aligned}
& \text { دراسة المميزات الغذائية لاصناف الحمص .Cicer arietinum L وخاصة ما يتعلق والمقائ } \\
& \text { بالصفات الظاهرية والزراعية }
\end{aligned}
$$



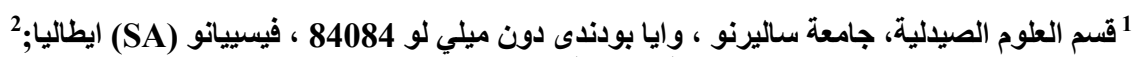

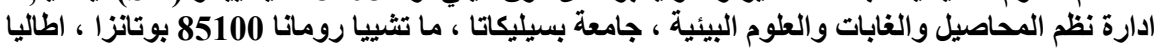

الملخص: يعتبر نبات الحمص واحدا من حبوب البقوليات الأكثر اهتماما لقيمته الغذائية وتحسينها الور اثي وخاصة لمقاومة Aschochyta rabiei



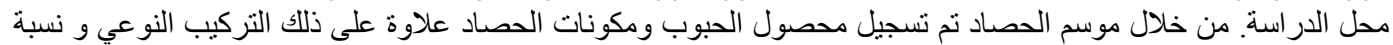

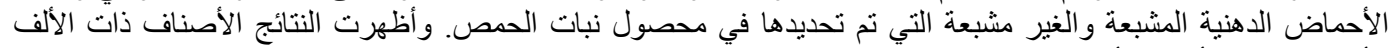

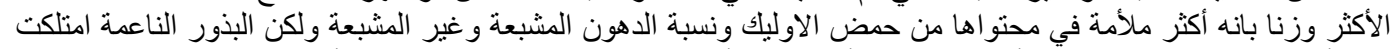

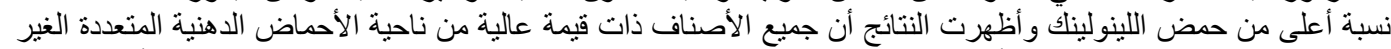

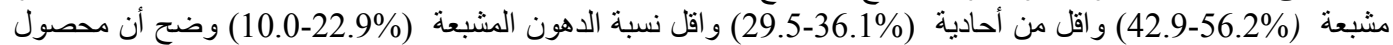

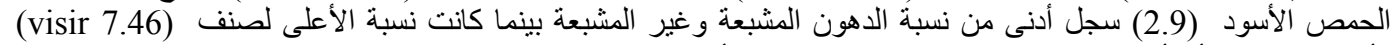

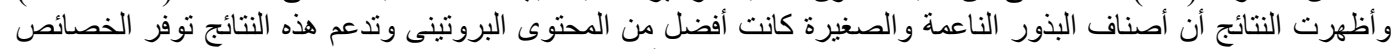





\footnotetext{
*Corresponding Author, Email: rastrelli@unisa.it
} 


\section{Introduction}

Chickpea (Cicer arietinum L.) is a cool-season food legume grown mainly by small farmers in many parts of the world. It is an important source of protein in the diets of the poor, and is particularly important in vegetarian diets. It is also being used increasingly as a substitute for animal protein. Chickpea is an annual plant ranging from 20 to $100 \mathrm{~cm}$ in height, but tall types measuring more than $1.0 \mathrm{~m}$ are cultivated in some parts of Russia. The plant has a deep root system and is considered well adapted to dry areas. Pods range in length from 8 to $41 \mathrm{~mm}$ and in width from 6 to $15 \mathrm{~mm}$. Each pod usually contains two seeds. The 100 seed weight varies from less than $8 \mathrm{~g}$ to more than $70 \mathrm{~g}$. Based on seed size and shape, two main kinds of chickpea are recognized: Desi types, which have small, dark-brown seeds and a rough coat, and Kabuli types, which have creamy-white seeds that are larger, with a smoother coat (Singh, 1997; Kaur and Singh, 2005)

Grain legumes, notable protein sources, constitute an important part of human diet in many parts of the world and they find an excellent utilization as functional food. These crops also serve as sources of income to small-and largescale farmers in developing countries (Ahmed and Yusuf, 2007). Chickpea (Cicer arietinum L.) is a cool-season food legume grown mainly by small farmers in many parts of the world. It is an important source of protein in the diets of the poor, and is particularly important in vegetarian diets. It is also being used increasingly as a substitute for animal protein. Chickpea is considered one of the most important species for the sustainable system of the Mediterranean area. Moreover the chickpea can play an important role in sustainable crop systems due to low cultural requirements (De Falco et al., 2000) while $\mathrm{N}_{2}$ fixation and quality of plant residues lead to highest yields for the following crops (De Falco et al., 2000). Recent studies pointed out the availability of new Mediterranean varieties marked by potential high yields and favourable agronomic characteristics, particularly in relation to mechanical harvesting (Abbate et al., 2001). These varieties can be distinguished by different seeds size and wrinkledness. In particular, the large and wrinkled seeds are usually preferred by the consumers, while those small and smooth are destined for the flours and dietetics production.

Different authors have studied the influence of cropping conditions and variety on the contents of antinutrients and the proximate composition of chickpeas. Coskuner and Karababa (2003) have reported the effects of location and variety on the morphological characteristics and cooking quality of chickpeas, while Nikolopoulou et al. (2006) have reported a study on the combined influence between cultivation area, year and variety on the proximate composition and antinutrients contents of chickpeas. There has also been some sporadic correlation between the proximate composition and nutritional quality with the biotype or cultivar of chickpeas (Rincón et al., 1998; Al-Karaki et al., 1999; Kaur and Singh, 2005). Based on seed size and shape, two main kinds of chickpea are recognized: Desi types, which have small, dark-brown seeds and a rough coat, and Kabuli types, which have creamy-white seeds that are larger, with a smoother coat. Significant differences between Kabuli and Desi types have been observed with regard to some technological parameters and chemical composition by several workers (Gil et al., 1996; Kaur and Singh, 2005). Kabuli type generally has lower fibre, higher starch, and more fat than desi type. No noticeable differences in protein content, amino acid content and true digestibility were found between desi and kabuli, whereas kabuli showed considerably higher biological value than desi (Wang et al., 2010).

For the reasons given above, there is a continuous need to study the newly 
evolved cultivars, in particular for their agronomic and chemical characteristics. Therefore, this study was carried out to characterize the cultivars of chickpea available in Italy with respect to morphological and agronomic parameters, in order to highlight their nutritional significance. In particular, grain samples were analysed for determining proximate composition, fatty acids content and saturated and unsaturated ratio.

\section{Material and Methods}

\section{Samples and agronomic characterization}

The research has been carried out during the years 2005-2006 at the experimental field of the Department of Crop System Forestry and Environmental
Science (Guardia Perticara - PZ - Italy) in a hilly representative area of the Basilicata Region, at $720 \mathrm{~m}$ a.s.l. on a flat, deep clayloam soil with low amount of organic matter (1.29\%) and phosphorus (58 ppm) but a satisfactory content of total nitrogen $(0.115 \%)$ and exchangeable potassium (345 ppm).

Fifteen chickpea cultivars have been collected and compared: eight varieties recorded into the Italian National Register, two commercial cultivars, three lines under selection and two agro-ecotypes. The cultivars had light-colored testa with except of "Nero" and they were characterized from different seeds size and wrinkledness (Table 1 and Figure 1).

Table 1. Chickpea cultivars and seeds characteristics.

\begin{tabular}{|c|c|c|c|c|}
\hline \multirow{2}{*}{\multicolumn{2}{|c|}{ Cultivars }} & \multicolumn{2}{|c|}{ Seeds } & \multirow{2}{*}{ Supplier } \\
\hline & & Size & Wrinkledness & \\
\hline Sultano & Variety $(1990)^{*}$ & $\mathrm{~S}$ & SS & Sativa Soc. Coop.- Cesena (FC) \\
\hline Cairo & Commercial & M & SS & Agra - M.Lombarda (Ravenna) \\
\hline Vulcano & Variety $(1996)^{*}$ & $\mathrm{~S}$ & SS & Eurogen - Piazza Armerina (EN) \\
\hline Etna & Variety $(1996)^{*}$ & $\mathrm{~S}$ & SS & Eurogen - Piazza Armerina (EN) \\
\hline Principe & Variety $(1990)^{*}$ & M & WS & Sais - Cesena (FC) \\
\hline Molian & Variety $(1999)^{*}$ & $\mathrm{~S}$ & SS & ISRGV Center "P. Iannelli" (Un.Basilicata) \\
\hline$P A 3$ & Line & M & SS & Dept.Envir.Ter.Agr. (University of Palermo) \\
\hline PA 21 & Line & M & SS & Dept.Envir.Ter.Agr. (University of Palermo) \\
\hline PA 34 & Line & $\mathrm{M}$ & SS & Dept.Envir.Ter.Agr. (University of Palermo) \\
\hline Ares & Variety & $\mathrm{S}$ & SS & Sais-Cesena (FC) \\
\hline Corlian & Variety $(1999)^{*}$ & $\mathrm{~S}$ & SS & ISRGV Center "P.Iannelli" (Un.Basilicata) \\
\hline Visir & Variety $(1998)^{*}$ & $\mathrm{~L}$ & WS & Asgrow - Veg. Seed - Lodi \\
\hline $\begin{array}{l}\text { Cancell } \\
\text { ara }\end{array}$ & Agro-ecotype & $\mathrm{L}$ & WS & Dept.CSFES (University of Basilicata) \\
\hline Krema & Commercial & $\mathrm{L}$ & WS & Agra-M.Lombarda - Ravenna \\
\hline Nero & Agro-ecotype & $\mathrm{S}$ & WS & Dept.Envir.Ter.Agr. (University of Palermo) \\
\hline
\end{tabular}

$*=$ Year of Registration; $\mathrm{S}=$ small seed $(\leq 300 \mathrm{~g}) ; \mathrm{M}=$ middle seed $(>300 \mathrm{~g},<400 \mathrm{~g}) ; \mathrm{L}=$ large seed $(\geq 400 \mathrm{~g}) ; \mathrm{SS}=$ smooth seed; $\mathrm{WS}=$ wrinkled seed. 


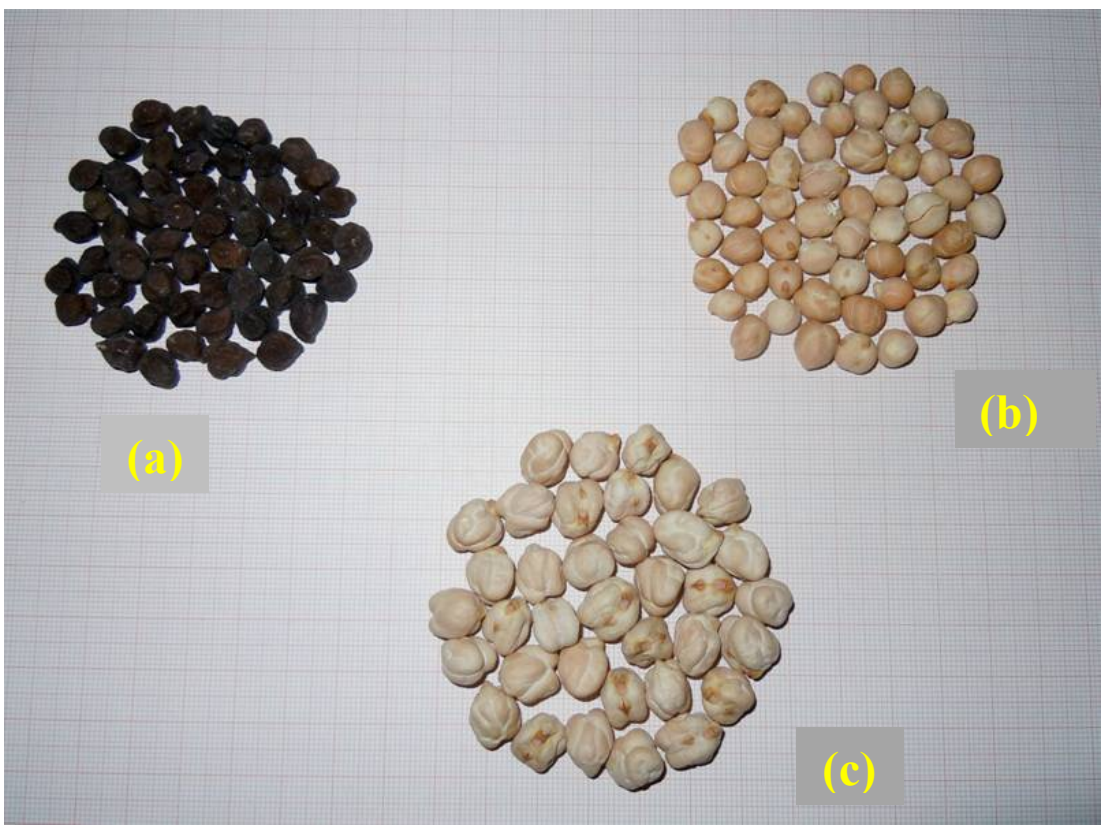

Figure 1. Seeds of chickpea: a) small wrinkled seeds; b) large wrinkled seeds; c) small smooth seeds.

Cultural practices have been adopted according to the results of previous research in the environment of the trial (De Falco et al., 2000). The sowing (19 December 2000) was done on a soil previously ploughed at $20 \mathrm{~cm}$ and manured with 69 units of $\mathrm{P}_{2} \mathrm{O}_{5}$ per hectare; density was of 60 seeds $\mathrm{m}^{-2}$. The plots of $10 \mathrm{~m}^{2}$ were distributed according to a randomized block design with three replications. During the cultural cycle resistance and sensitiveness to Ascochyta rabiei have been evaluated. At harvesting (30 June 2001), grain yield and yield components were registered from an assay area of $1 \mathrm{~m}^{2}$ (Figure 2). The data were statistically analysed.

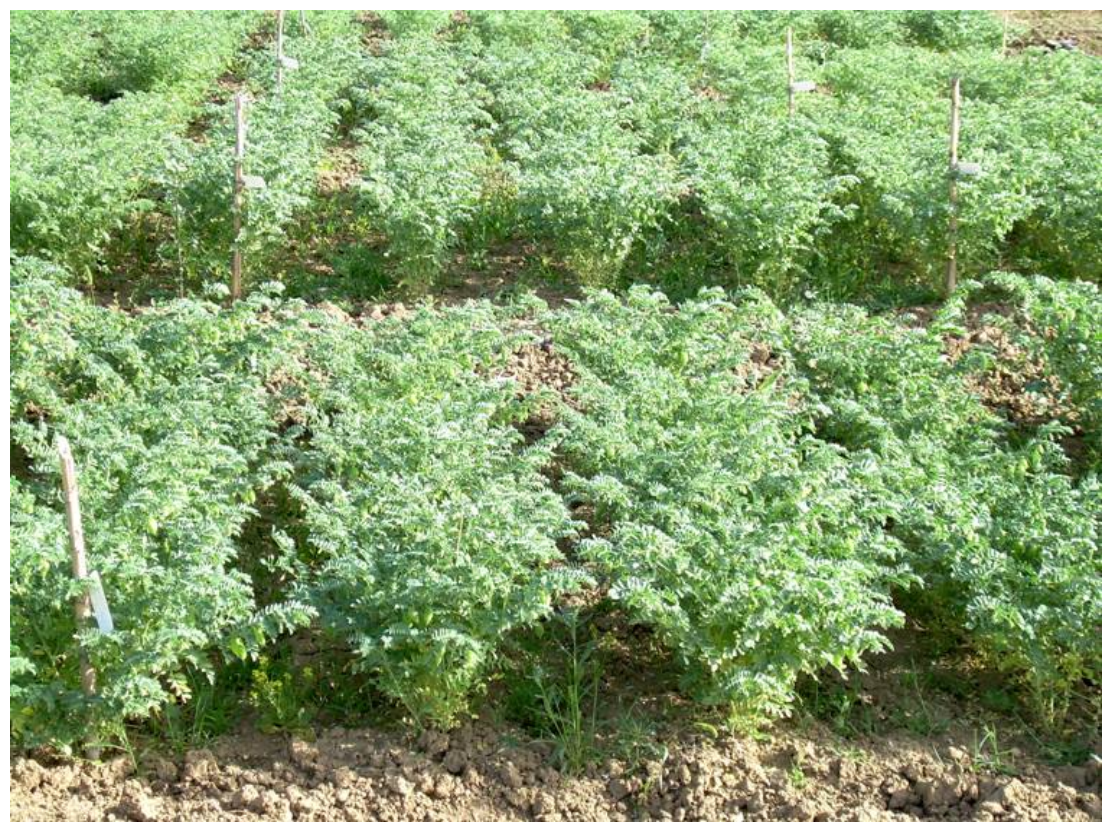

Figure 2. View of the crop at the ripening stage. 


\section{Standards and Solvents}

Pure fatty acid standards were purchased from Sigma Chemicals (Milan, Italy). All organic solvents were products of Carlo Erba, Milano (Italy). Water was purified by a Milli- Qplus system from Millipore (Milford, MA).

\section{Proximate composition analysis}

For each sample dry seeds were milled to give a fine meal. The moisture content was determined by drying the samples in a Napco 430 oven at $130^{\circ} \mathrm{C}$ until a constant weight was obtained (AOAC 925.10). Crude protein content was calculated by Kjeldahl's method (6.25 $\times$ N) $($ AOAC 920.87) in a Tecator 2020 digestor and Kjeltec 1030 autoanalyzer. Ash content was determined by drying ash in a Lindberg 51442 muffle furnace at $550^{\circ} \mathrm{C}$ for $24 \mathrm{~h}$ (AOAC 923.03). Fat content was determined from the weight of the combined dichloromethane extracts. The extraction was carried out using the Soxhlet system (AOAC, 1990) until exhaustion. Crude fibre was determined in a Tecator Fibertec 1010 fiber digester (AOAC, 1990). Carbohydrates were calculated as "Nitrogen free extract" according to the formula: Carbohydrates $=$ $100-(\%$ moisture $+\%$ protein $+\%$ crude fibre $+\%$ fat $+\%$ ash).

\section{Fatty acids transesterification}

About $0.5 \mathrm{mg}$ of the residues were mixed with a same volume of a mixture methanol/sulphuric acid 9:1 in a sealed glass. The samples were placed in oven at $110^{\circ} \mathrm{C}$ for $1 \mathrm{~h}$ and then cooled, a drop of the surnatants were picked up, diluted with ethylic ether, and, subsequently, injected in the GC/MS $(1 \mu 1)$. A mixture of standard methyl esters, containing equal weights of methyl acetate, methyl propionate, methyl butyrate, methyl caproate, methyl caprylate, methyl caprate, methyl laurate, methyl myristate, methyl palmitate, methyl palmitoleate, methyl stearate, methyl oleate, methyl linoleate, methyl linolenate, methyl arachidate, methyl behenate, and methyl lignocerate, was used for comparison.

\section{GC-MS analysis}

A Finnigan GCQ (Trace GC 2000 coupled with a Polaris MSD) gas chromatography-mass-spectrometer, with a split/splitless capillary injection port was used for all analyses. Samples were separated on HP-FFAP capillary column $(25 \mathrm{~m} \times 0.32 \mathrm{~mm} \times 0.52 \mu \mathrm{m})$. (Hewlett and Packard). The temperature program applied was as follows: $150{ }^{\circ} \mathrm{C}$ for $2 \mathrm{~min}$, $150-250{ }^{\circ} \mathrm{C}$ at $6^{\circ} \mathrm{C} / \mathrm{min}$, and $250^{\circ} \mathrm{C}$ for 15 min. The total run time was $31.5 \mathrm{~min}$. Ultrahigh purity helium with an inline oxygen trap was used as carrier gas at a flow rate of $0.4 \mathrm{ml} / \mathrm{min}$. The injector was heated to $260{ }^{\circ} \mathrm{C}$ and was on split mode with a split ratio of $1: 10$, the injection volume was $1 \mu \mathrm{L}$. The MSD was acquiring data in the full scan mode (mass range 40800 ) at $2.9 \mathrm{scans} / \mathrm{s}$, with a multiplier voltage of $2000 \mathrm{~V}$ and ionisation energy of $70 \mathrm{eV}$. The identification of every component has been performed comparing the retention times with standard samples and subsequently confirming them by the analysis of the mass spectra and by the relative fragmentation patterns.

\section{Statistical analysis}

The chemical analysis of the 15 varieties were carried out in three replicates. Statistical analyses were performed by Mann-Whitney U Test (Hollander and Wolfe, 1999). Minimal acceptance of statistical significance was $p$ $<0.05$. The Pearson matrix was performed in order to evaluate some significative correlations between the agronomic and the chemical parameters. 


\section{Results and discussion}

The rainfalls during the trial period were lower $(360.2 \mathrm{~mm})$ than the average of 25 years $(406.3 \mathrm{~mm})$, particularly during the spring time. The temperatures registered during the winter months were generally lower with respect to the average of 25 years while they were higher during the spring.

The sensitiveness to Ascochyta rabiei is one of the factors that limit the chickpea cultivars yield, and it is particularly dangerous for the autumn sowing during rainy spring time. In fact rainfalls and temperature time-course favourable to the fungus development can even provoke the total dryness of the plants (Shahid et al., 2009). During the year of the trial, characterized by low rainfalls in the spring time, only the agro-ecotype "Cancellara" and the old variety "Principe" showed a medium infection due to the pathogen, the commercial variety "Krema" a light infection, while the varieties of more recent constitution and the lines in progress of selection, generally showed high resistance.

The productive results, reported in Table 2, showed high grain yields, ranging from 2.2 and $3.5 \mathrm{t} \mathrm{ha}^{-1}$, with the exception of "Cancellara" and "Principe" which were partially damaged by Ascochyta and in fact the number of plants at harvest (25 plant $\mathrm{m}^{-}{ }^{2}$ ) was much more lower with respect to sowing density. The most productive cultivars resulted to be "Vulcano", "Cairo", "PA 3", "PA 21" and "PA 34", all characterized by small or medium seeds. Nevertheless, a very high grain yield was registered also for the cultivar with large seed "Visir" $\left(2.8 \mathrm{t} \mathrm{ha}^{-1}\right)$. The height of the plants was higher for "Ares", "Corlian" and "Sultano". For these cultivars, the highest values of the height of the $1^{\text {st }}$ pod, superior to $50 \mathrm{~cm}$, were also registered. Anyway this parameter was always higher than $30 \mathrm{~cm}$, excepted for the agro-ecotypes "Nero" and "Cancellara", pointing out a good adaptation to the mechanization of the harvest for all the cultivars under improvement.

Table 2. Grain yields and yields components of the fifteen Cicer cultivars.

\begin{tabular}{lcccccccc}
\hline \multirow{2}{*}{ Cultivar } & $\begin{array}{c}\text { Grain } \\
\text { yield }\end{array}$ & $\begin{array}{c}\text { Harvest } \\
\text { index }\end{array}$ & $\begin{array}{c}\text { Plants } \\
\text { height }\end{array}$ & $\begin{array}{c}\text { st } \\
\text { height }\end{array}$ & $\begin{array}{c}\text { Pods } \\
\text { per plant }\end{array}$ & $\begin{array}{c}\text { Fertile } \\
\text { pods }\end{array}$ & $\begin{array}{c}\text { Seeds } \\
\text { per pod }\end{array}$ & $\begin{array}{c}\mathbf{1 0 0 0} \\
\text { seeds } \\
\text { weight }\end{array}$ \\
\cline { 2 - 9 } $\left.\mathbf{( t ~ h a ) ~}^{-1}\right)$ & $\mathbf{( \% )}$ & $\mathbf{( c m )}$ & $\mathbf{( c m )}$ & $\mathbf{( n )}$ & $\mathbf{( \% )}$ & $\mathbf{( n )}$ & $\mathbf{( g )}$ \\
\hline Sultano & 2.8 & 34 & 73 & 50 & 19 & 91 & 1.4 & 300 \\
Cairo & 3.5 & 40 & 63 & 38 & 13 & 91 & 1.3 & 385 \\
Vulcano & 3.5 & 43 & 64 & 38 & 13 & 85 & 1.4 & 260 \\
Etna & 2.5 & 32 & 69 & 43 & 13 & 96 & 1.3 & 283 \\
Principe & 1.9 & 37 & 55 & 32 & 18 & 91 & 1.3 & 383 \\
Molian & 2.5 & 35 & 66 & 44 & 16 & 86 & 1.3 & 250 \\
PA 21 & 3.1 & 37 & 56 & 35 & 13 & 88 & 1.3 & 303 \\
PA 34 & 3.1 & 37 & 62 & 40 & 15 & 88 & 1.3 & 301 \\
PA 3 & 3.1 & 39 & 59 & 37 & 14 & 89 & 1.2 & 306 \\
Ares & 2.9 & 33 & 75 & 53 & 15 & 91 & 1.2 & 323 \\
Corlian & 2.6 & 35 & 74 & 54 & 11 & 89 & 1.3 & 300 \\
Visir & 2.8 & 38 & 67 & 45 & 11 & 93 & 1.4 & 453 \\
Cancellara & 1.5 & 38 & 48 & 28 & 13 & 89 & 1.2 & 566 \\
Krema & 2.2 & 39 & 56 & 38 & 8 & 91 & 1.3 & 493 \\
Nero & 2.2 & 43 & 49 & 28 & 13 & 91 & 1.2 & 281 \\
MSD (P=0.05) & 0.4 & 5 & 3 & 3 & 2 & 7 & 0.1 & 40 \\
\hline
\end{tabular}


The percentage of fertile pods with respect to the total, resulted quite low and ranged between $85 \%$ for "Vulcano" and $96 \%$ for "Etna". Small differences were registered among the cultivars for the number of seeds per pod that ranged between 1.2 and 1.4. The weight of 1000 seeds resulted superior to $400 \mathrm{~g}$ for the cultivars "Cancellara", "Krema" and "Visir". Particularly "Cancellara" resulted very interesting, because even if it was very sensitive to the Anthracnose, it has showed a very high weight of 1000 seeds (566 g).

The analysis of agronomical data showed that the grain yield was in direct relation with the number of plants $\mathrm{m}^{-2}$ $\left(0.65^{* *}\right)$ and the number of seeds per pod $\left(0.51^{*}\right)$, while it was in inverse relation with the weight of the seeds $\left(-0.53^{*}\right)$.
The results of the chemical analyses, performed in order to determine the composition of the 15 chickpea flours, are reported in Table 3 . For all the analyzed samples high proteins content has been found and it ranged from $15.22 \%$ for the variety "Visir" and $23.53 \%$ for the variety "Molian". Little differences were registered among the cultivars for the ash content that ranged between $2.72 \%$ and $3.28 \%$. Also the total of soluble and insoluble dietary fibre fractions ranged between 4.80 (cv. PA 21) and $6.02 \%$ (cv. Cancellara) of the chekpea seeds indicated high percentage when compared with commonly consumed seed legumes. The lipids content showed the higher contents for the cultivars "PA 21" (6.19\%), "Etna" (6.01\%) and "Pa 34" $(5.95 \%)$, while the lowest content has been registered for the cultivar "Cairo" (4.04\%).

Table 3. Proximate composition (\%) of the fifteen chickpea cultivar flours ${ }^{\mathrm{a}}$.

\begin{tabular}{lrlllll}
\hline Cultivars & \multicolumn{1}{l}{$\begin{array}{l}\text { Moisture } \\
(\%)\end{array}$} & $\begin{array}{l}\text { Crude } \\
\text { proteins } \\
(\%)\end{array}$ & $\begin{array}{l}\text { Ash } \\
\mathbf{( \% )}\end{array}$ & Lipids (\%) & $\begin{array}{l}\text { Crude } \\
\text { fiber (\%) }\end{array}$ & $\begin{array}{l}\text { Carbohydrates } \\
(\%)\end{array}$ \\
\hline Sultano & \multicolumn{1}{c}{ 9.77 \pm 0.02} & $19.33 \pm 0.35$ & $3.13 \pm 0.22$ & $4.69 \pm 0.03$ & $5.10 \pm 0.08$ & $57.98 \pm 0.32$ \\
Cairo & $10.19 \pm 0.04$ & $20.51 \pm 0.06$ & $2.89 \pm 0.11$ & $4.04 \pm 0.32$ & $5.08 \pm 0.04$ & $57.29 \pm 0.27$ \\
Vulcano & $9.36 \pm 0.10$ & $20.54 \pm 0.06$ & $2.78 \pm 0.05$ & $5.60 \pm 0.17$ & $4.93 \pm 0.11$ & $56.79 \pm 0.18$ \\
Etna & $10.01 \pm 0.02$ & $20.34 \pm 0.22$ & $3.21 \pm 0.08$ & $6.01 \pm 0.03$ & $5.71 \pm 0.04$ & $54.72 \pm 0.31$ \\
Principe & $9.83 \pm 0.08$ & $17.51 \pm 0.25$ & $3.04 \pm 0.07$ & $4.23 \pm 0.11$ & $5.47 \pm 0.16$ & $59.92 \pm 0.19$ \\
Molian & $9.91 \pm 0.12$ & $23.53 \pm 0.11$ & $2.97 \pm 0.22$ & $4.40 \pm 0.15$ & $5.04 \pm 0.09$ & $54.15 \pm 0.41$ \\
PA 21 & $10.15 \pm 0.05$ & $20.74 \pm 0.27$ & $2.72 \pm 0.12$ & $6.19 \pm 0.04$ & $4.80 \pm 0.05$ & $55.40 \pm 0.31$ \\
PA 3 & $10.11 \pm 0.03$ & $18.96 \pm 0.06$ & $2.74 \pm 0.06$ & $5.50 \pm 0.01$ & $6.01 \pm 0.05$ & $56.68 \pm 0.20$ \\
PA 34 & $10.24 \pm 0.05$ & $20.61 \pm 0.56$ & $2.95 \pm 0.18$ & $5.95 \pm 0.26$ & $5.12 \pm 0.10$ & $55.13 \pm 0.19$ \\
Ares & $9.83 \pm 0.01$ & $20.56 \pm 0.09$ & $3.23 \pm 0.01$ & $4.70 \pm 0.57$ & $4.87 \pm 0.23$ & $56.81 \pm 0.17$ \\
Corlian & $10.43 \pm 0.05$ & $20.26 \pm 0.30$ & $2.92 \pm 0.11$ & $5.67 \pm 0.11$ & $5.11 \pm 0.21$ & $55.61 \pm 0.31$ \\
Visir & $9.99 \pm 0.11$ & $15.22 \pm 0.09$ & $2.73 \pm 0.20$ & $5.28 \pm 0.25$ & $4.65 \pm 0.11$ & $62.13 \pm 0.34$ \\
Cancellara & $9.56 \pm 0.07$ & $19.61 \pm 0.12$ & $2.74 \pm 0.05$ & $5.24 \pm 0.01$ & $6.02 \pm 0.14$ & $56.83 \pm 0.18$ \\
Krema & $9.77 \pm 0.07$ & $17.96 \pm 0.11$ & $2.90 \pm 0.22$ & $4.95 \pm 0.42$ & $5.34 \pm 0.12$ & $59.08 \pm 0.29$ \\
Nero & $9.86 \pm 0.06$ & $18.92 \pm 0.17$ & $3.28 \pm 0.20$ & $4.55 \pm 0.22$ & $5.67 \pm 0.09$ & $57.72 \pm 0.16$ \\
\hline
\end{tabular}

${ }^{\mathrm{a}}$ Mean value of three replications \pm SD. Standard deviations were below $10 \%$.

The study of the lipidic fraction has shown interesting qualitative and quantitative contents, as reported in Table 4, with differences among the cultivars. The palmitic acid content ranged from the $10.06 \%$ of "Visir" to the $15.98 \%$ of "PA 21 " with the exclusion of the agro-ecotype "Nero" which reached the percentage of
$22.92 \%$. The stearic acid content resulted almost the same in all the cultivars analyzed $(\sim 1.4 \%)$, except for the variety "Vulcano" (3.56\%) and the line "PA 21" $(0.71 \%)$. The content of the oleic acid, which represents the great part of the monounsatured fatty acids, ranged from $29.55 \%$ of the variety "Molian" to $36.15 \%$ 
of "Sultano". The linoleic acid content ranged from 45.17\% ("PA 21") and $53.68 \%$ ("Corlian") with except of the agro-ecotype "Nero" that showed the lowest value $(42.05 \%)$. For this cultivar was registered also the lowest percentage of linolenic acid content $(0.84 \%)$ followed from the agro-ecotype "Cancellara" $(1.85 \%)$. The highest value was recorded for the variety "Vulcano" (4.63\%) while for the other cultivars the value of linolenic acid ranged from $2.14 \%$ and $3.22 \%$. Low content of other fatty acids (lauric, palmitoleic and arachidic) were also found, but the concentrations were lower than $2.0 \%$. The results have confirmed high concentrations of linoleic and oleic acid, according to previous researches (Gül et al., 2008).

Table 4. Fatty acids content (\%) of the fifteen chickpea cultivar flours.

\begin{tabular}{|c|c|c|c|c|c|c|c|c|}
\hline \multirow[b]{2}{*}{ Cultivars } & \multicolumn{8}{|c|}{ Fatty acids $(\%)^{\mathrm{a}}$} \\
\hline & $\begin{array}{l}\text { Lauric } \\
\text { (C12:0) }\end{array}$ & $\begin{array}{l}\text { Palmitic } \\
\text { (C16:0) }\end{array}$ & $\begin{array}{l}\text { Palmitoleic } \\
\text { (C16:1) }\end{array}$ & $\begin{array}{l}\text { Stearic } \\
\text { (C18:0) }\end{array}$ & $\begin{array}{l}\text { Oleic }^{\mathrm{b}} \\
\text { (C18:1) }\end{array}$ & $\begin{array}{l}\text { Linoleic } \\
\text { (C18:2) }\end{array}$ & $\begin{array}{l}\text { Linolenic } \\
\text { (C18:3) }\end{array}$ & $\begin{array}{l}\text { Arachidic } \\
(C: 20)\end{array}$ \\
\hline Sultano & 0.21 & 11.43 & 0.49 & 1.44 & 36.15 & 47.61 & 2.14 & 0.53 \\
\hline Cairo & 0.27 & 11.22 & 0.41 & 1.42 & 35.53 & 48.24 & 2.35 & 0.56 \\
\hline Vulcano & 0.33 & 13.60 & 0.51 & 3.56 & 31.45 & 45.29 & 4.63 & 0.63 \\
\hline Etna & 0.22 & 12.11 & 0.45 & 1.24 & 31.24 & 51.74 & 2.39 & 0.61 \\
\hline Principe & 0.23 & 10.91 & 0.42 & 1.31 & 33.21 & 51.02 & 2.34 & 0.56 \\
\hline Molian & 0.37 & 12.27 & 0.47 & 1.26 & 29.55 & 52.44 & 3.12 & 0.52 \\
\hline PA 21 & 0.43 & 15.98 & 0.49 & 0.71 & 33.31 & 45.17 & 3.22 & 0.69 \\
\hline PA 3 & 0.37 & 11.73 & 0.51 & 1.29 & 32.76 & 50.29 & 2.43 & 0.62 \\
\hline PA 34 & 0.29 & 12.39 & 0.43 & 1.31 & 29.91 & 52.42 & 2.74 & 0.51 \\
\hline Ares & 0.31 & 11.93 & 0.41 & 1.42 & 32.76 & 49.99 & 2.56 & 0.62 \\
\hline Corlian & 0.39 & 10.75 & 0.45 & 1.33 & 30.37 & 53.68 & 2.51 & 0.52 \\
\hline Visir & 0.35 & 10.06 & 0.49 & 1.41 & 35.03 & 49.59 & 2.39 & 0.68 \\
\hline Cancellara & 0.33 & 13.23 & 0.47 & 1.97 & 31.58 & 50.03 & 1.85 & 0.54 \\
\hline Krema & 0.24 & 11.54 & 0.45 & 1.37 & 34.77 & 48.57 & 2.41 & 0.65 \\
\hline Nero & 0.33 & 22.92 & 0.43 & 1.43 & 31.32 & 42.05 & 0.84 & 0.68 \\
\hline
\end{tabular}

${ }^{a}$ FID area percents were corrected to wt \% according to total weight. Data are the means of five experiments performed in triplicate. Standard deviations were below $10 \%$. ${ }^{\mathrm{b}}$ Cis9-C18:1 + Cis11C18:1.

Table 5 reported the percentages of polyunsaturated (PUFA) and saturated fatty acids found in the flour of the 15 cultivars of chickpea analyzed. All the cultivars showed high values of polyunsaturated fatty acids, always higher with respect to monounsaturated fatty acids. The lowest value of PUFA was $42.89 \%$ for the agroecotype "Nero", while the highest was
$56.19 \%$ for the variety "Corlian". The saturated fatty acids content was quite low: it was higher than $20 \%$ only for "Nero" $(24.68 \%)$. In consequence, this cultivar showed also the lowest unsaturated/saturated ratio (3.05), while the highest was noticed for the cultivar "Visir" (7.46). Anyway, the great part of the cultivars showed a value close to 6 . 
Table 5. Polyunsaturated and saturated fatty acids of the fifteen chickpea cultivar flours.

\begin{tabular}{llll}
\hline Cultivars & $\begin{array}{l}\text { PUFA } \\
(\mathbf{\% )}\end{array}$ & $\begin{array}{l}\text { Saturated } \\
\mathbf{( \% )}\end{array}$ & $\begin{array}{l}\text { Insaturated/ } \\
\text { saturated }\end{array}$ \\
\hline Sultano & 49.75 & 13.08 & 6.65 \\
Cairo & 50.59 & 12.91 & 6.75 \\
Vulcano & 49.92 & 17,49 & 4.72 \\
Etna & 54.13 & 13.57 & 6.37 \\
Principe & 53.36 & 12.45 & 7.03 \\
Molian & 55.56 & 13.90 & 6.19 \\
PA 21 & 48.39 & 17.12 & 4.84 \\
PA 3 & 52.72 & 13.39 & 6.47 \\
PA 34 & 55.16 & 13.99 & 6.15 \\
Ares & 52.55 & 13.66 & 6.32 \\
Corlian & 56.19 & 12.47 & 7.02 \\
Visir & 51.98 & 11.82 & 7.46 \\
Cancellara & 51.88 & 15.53 & 5.44 \\
Krema & 50.98 & 13.15 & 6.60 \\
Nero & 42.89 & 24.68 & 3.05 \\
\hline
\end{tabular}

In order to individualize possible mathematical correlations between the agronomic parameters and the chemical characteristics, the Pearson matrix of correlation has been elaborated. Tables 6 reported only the parameters where some relations were near to statistical significance. Also if the correlation coefficients reached the statistical significance only in some case with a reduced interpretation of the variability, some remarks can be made.

Table 6. Pearson matrix for the analyzed parameters.

\begin{tabular}{llllllll}
\hline & $\begin{array}{l}\text { Ash } \\
(\%)\end{array}$ & $\begin{array}{l}\text { Proteins } \\
(\%)\end{array}$ & $\begin{array}{l}\text { Lipids } \\
\mathbf{( \% )}\end{array}$ & $\begin{array}{l}\text { Stearic } \\
\text { ac. (\%) }\end{array}$ & $\begin{array}{l}\text { Oleic } \\
\text { ac. (\%) }\end{array}$ & $\begin{array}{l}\text { Linolenic } \\
\text { ac. (\%) }\end{array}$ & $\begin{array}{l}\text { Unsaturated/ } \\
\text { Saturated }\end{array}$ \\
\hline Harvest index & $-0.53^{*}$ & 0.04 & 0.09 & $-0.51^{*}$ & 0.14 & 0.45 & 0.08 \\
1000 seeds weight & 0.06 & $-0.44^{*}$ & -0.29 & -0.01 & $0.39^{*}$ & -0.32 & $0.26^{*}$ \\
Wrinkledness & -0.35 & $-0.61^{*}$ & $-0.52^{*}$ & -0.12 & -0.12 & $-0.56^{*}$ & 0.01 \\
Grain yield & -0.17 & 0.32 & -0.09 & 0.18 & 0.17 & 0.57 & 0.05 \\
\hline
\end{tabular}

The values near to statistical significance $(>0.05)$ are showed up by asterisks $(*)$.

The harvest index was negatively correlated to the ash and the stearic acid content. The 1000 seeds weight was in direct relation with the oleic acid content and the unsaturated/saturated ratio, while it was in inverse relation with proteins content. Negative correlations have been reported between the seeds wrinkledness and the proteins and the lipids contents and the linolenic acid. At last grain yield was not related to any parameters.
The results pointed out a relation of agronomic parameters with lipids and fatty acids composition as it was reported by Gil et al. (1996) with differences in relation to seeds weight and wrinkledness. The cultivars with high 1000 seeds weight showed a more favourable oleic acid content and unsaturated/saturated ratio but the cultivar with smooth seeds had a higher content in linolenic acid. The cultivars with small and smooth seeds showed a better content of proteins. 
These results highlight the availability of choosing among a large number of cultivars of chickpea characterized from different nutritional value and potential utilization as functional food, without interaction with their yield ability. Moreover, the results underlines that there isn't a really justify from nutritional point of view to the actually preference at the consumption of cultivars with great and wrinkled seeds.

\section{Conclusions}

With the present work the availability of cultivars of chickpea that show high yield, resistance against the attack of Ascochyta rabiei and that can result proper for the mechanical harvest due to the high height of the first fertile pod, and with a high nutritional value has been evidenced. The study of the lipidic fraction that contributes together with the proteic content to the nutritional and functional value of a food source has shown interesting qualitative and quantitative contents. By considering the grain dimensions, between the most productive cultivars there are both those with small seeds, proper for processing and flours preparation, and those with great and wrinkled seeds, generally used for the human feeding as grain. Among the first ones, we can mention the cultivars "Vulcano", "Sultano", "PA 3", "PA 21" and "PA 34" while among the second ones the cultivars "Visir", "Krema" and "Cairo". These results showed availability of seeds with favourable characteristics useful for different utilization. In particular, the cultivars with small and smooth seeds that are usually not preferred by consumers seem, instead, to be very interesting for processing in nutritional foods, flours and dietetics.

\section{References}

Abbate, V., G. Avola, O. Sortino, A. Marletta, R. Tuttobene, A. Barbera, D. Giambalvo, L. Stringi, A. S. Frenda, G. Di Miceli, P. Trapani, V.
Chiappitelli, G. Landi, E. De Falco, A., Pardo, L. Matteu, B. D’Onofrio and A. Iorio. 2001. Valutazione di varietà di fava, cece, pisello proteico, lenticchia e cicerchia. L'Informatore Agrario 57(39):67-75.

Ahmed, B. I. and A. U. Yusuf. 2007. Host-plant resistance: A viable non chemical and environmentally friendly strategy of controlling stored products pests-a review. Emir. J. Food Agric. 19(1):01-12.

Al-Karaki, G. N., K. I. Ereifej and M. K. Hammouri. 1999. Relationships between seed yield and chemical composition of field peas grown under semi-arid Mediterranean conditions. J. Agron. Crop Sci. 182(4):279-284.

AOAC. 1990. Official Methods of Analysis. 15th ed. Association of Official Analytical Chemists, Arlington, VA AOAC. 1990. Official Methods of Analysis. 15th ed. Association of Official Analytical Chemists, Arlington, VA.

Coskuner, Y. and E. Karababa. 2003. Effect of location and soaking treatments on the cooking quality of some chickpea breeding lines. Intl. J. Food Sci. Technol. 38(7):751-757.

De Falco, E., M. Amato, G. Landi, A. S. De Franchi and F. Basso. 2000. Valutazione di sistemi colturali sostenibili nella collina lucana. Rivista di Agron. 34:337-344.

Gil, J., S. Nadal, D. Luna, M. T. Moreno and A. De Haro. 1996. Variability of some physicochemical characters in desi and kabuli chickpea types. J. Sci. Food Agric. 71(2):179-184.

Gül, M. K., C. O. Egesel, and H. Turhan. 2008. The effects of planting time on fatty acids and tocopherols in chickpea. Eur. Food Res. Technol. 226:517-522. 
Hollander, M. and D. A. Wolfe. 1999. Nonparametric Statistical Methods $\left(2^{\text {nd }} \mathrm{Ed}\right.$. $)$.

Kaur, M. and N. Singh. 2005. Studies on functional, thermal and pasting properties of flours from different chickpea (Cicer arietinum L.) cultivars. Food Chem. 91(3):403-411.

Nikolopoulou, D., K. Grigorakis, M. Stasini, M. Alexis and K. Iliadis. 2006. Effects of cultivation area and year on proximate composition and antinutrients in three different kabulitype chickpea (Cicer arientinum) varieties. Eur. Food Res. Technol. 223(6):737-741.

Rincón, F., B. Martìnez and M. V. Ibàñez. 1998. Proximate composition and antinutritive substances in chickpea (Cicer arietinum L.) as affected by the biotype factor. J. Sci. Food Agric. 79(2):382-388.
Shahid, A. A., B. Chaudhry, Mahmood-urRahman and S. Riazuddin. 2009. Detection of anti-fungal genes in chickpea (Cicer arietinum L.). Emir. J. Food Agric. 21(2):34-41.

Singh, K. B. 1997. Chickpea (Cicer arietinum L.). Field Crop Res. 53:161170.

Wang, X., W. Gao, J. Zhang, H. Zhang, J. Li, X. He and H. Ma. 2010. Subunit, amino acid composition and in vitro digestibility of protein isolates from Chinese kabuli and desi chickpea (Cicer arietinum L.) cultivars. Food Res. Int. 43:567-572. 